\title{
Hubungan Komunikasi Terapeutik Perawat Terhadap Kepuasan Pasien Rawat Inap Di Ruangan Interna Rumah Sakit Umum Daerah Poso
}

\author{
The Correlation of Nursing Therapeutic Communication Against Inpatient \\ Satisfaction in the Internal Room of the Poso Regional \\ Public Hospital
}

\author{
Fany Lairin Djala*
}

Program Studi S1 Keperawatan, STIKES Husada Mandiri Poso

Jalan Pulau Kalimantan No 29, Kabupaten Poso. Sulawesi Tengah. Indonesia

*Corresponding author

Email: fanylairin@gmail.com

\begin{tabular}{|c|c|}
\hline & $A b s t r a c t$ \\
\hline $\begin{array}{l}\text { Keywords : } \\
\text { Therapeutic } \\
\text { Communication, } \\
\text { Patient Satisfaction }\end{array}$ & $\begin{array}{l}\text { Background: In nursing practice, communication is an important tool for fostering } \\
\text { therapeutic relationships and can affect the quality of nursing services.Therapeutic } \\
\text { communication in health care services is very important to the patients satisfaction } \\
\text { level.Objective: to determine the correlation of nurse therapeutic communication against } \\
\text { inpatient satisfaction in the internal room at the Poso Regional Public Hospital Methods: } \\
\text { Using correlation analytic with cross sectional approach, with a total sample of } 49 \\
\text { respondents. Data were analyzed by chi square statistical test. Results: Showed that of } 26 \\
\text { respondents }(83.9 \%) \text { who said they were satisfied with the therapeutic communication of } \\
\text { nurses and those who said they were less satisfied were } 8 \text { respondents }(44.4 \%) \text {. } \\
\text { Respondents who stated that nurses who carried out therapeutic communication well were } \\
\text { as many as } 31 \text { respondents (63.3\%), and those who stated poor communication as many } \\
\text { as } 18 \text { respondents (63.3\%). The results of the statistical test analysis with Chi-Square } \\
\text { showed the value of }=0.01 \text { (<0.05) so that Ha was accepted and Ho was rejected } \\
\text { Conclusion: There is a relationship between nurses' therapeutic communication and the } \\
\text { satisfaction of inpatients in Poso Regional Hospital. }\end{array}$ \\
\hline
\end{tabular}

Kata kunci :

Kepuasan Pasien Komunikasi

Terapeutik,

A B S T R A K
Latar belakang : Dalam praktek keperawatan, komunikasi adalah suatu alat yang
penting untuk membina hubungan teraupetik dan dapat mempengaruhi kualitas pelayanan
keperawatan. Komunikasi terapeutik menjadi sangat penting karena dapat mempengaruhi
tingkat kepuasan pasien terhadap pelayanan kesehatan yang diberikan. Tujuan: untuk
mengetahui hubungan komunikasi terapeutik perawat terhadap kepuasan pasien rawat
inap di ruangan Interna Di Rumah Sakit Umum Daerah Poso. Metode: Menggunakan
analitik korelasi dengan pendekatan Cross Sectional, dengan jumlah sampel sebanyak 49
responden. Data dianalisis dengan uji statistik chi square. Hasil: menunjukkan bahwa
dari 26 responden ( $83,9 \%)$ yang mengatakan puas terhadap komunikasi terapeutik
perawat. Yang mengatakan kurang puas yaitu sebanyak 8 responden (44,4\%).
Responden yang menyatakan bahwa perawat yang melaksanakan komunikasi terapeutik
dengan baik yaitu sebanyak 31 responden (63,3\%). Yang menyatakan komunikasi
kurang baik yaitu sebanyak 18 responden $(63,3 \%)$. Hasil analisis uji statistik dengan Chi-
Square menunjukkan nilaip= 0,01 (< 0,05$)$ sehingga Ha diterima dan H0 ditolak.
Kesimpulan: Ada hubungan antara komunikasi terapeutik perawat terhadap kepuasan
pasien rawat inap di ruangan interna RSUD Poso




\section{LATAR BELAKANG}

Rumah sakit merupakan institusi pelayanan kesehatan bagi masyarakat dengan karakteristik tersendiri dan dipengaruhi oleh perkembangan ilmu pengetahuan kesehatan, kemajuan teknologi dan kehidupan sosial ekonomi masyarakat yang harus tetap mampu meningkatkan pelayanan yang lebih bermutu dan terjangkau oleh masyarakat agar terwujud derajat kesehatan yang setinggi-tingginya. Rumah sakit memiliki peran yang sangat strategis dalam upaya mempercepat peningkatan derajat kesehatan masyarakat. ${ }^{1}$

Rumah sakit dinyatakan berhasil, tidak hanya pada kelengkapan fasilitas yang diunggulkan, melainkan juga sikap dan layanan sumber daya manusia merupakan elemen yang berpengaruh signifikan terhadap pelayanan yang dihasilkan dan dipersepsikan pasien. Pasien mengharapkan pelayanan yang siap, cepat, tanggap dan nyaman terhadap keluhan penyakit pasien, menguasai pekerjaan, dan yang paling utama mampu berkomunikasi secara efektif dan mampu menanggapi keluhan pasien secara professional. Perawat sebagai ujung tombak pelayanan terhadap pasien dan keluarganya di rumah sakit, karena frekuensi pertemuannya dengan pasien yang paling sering. ${ }^{2}$

Komunikasi dalam praktek keperawatan, merupakan aspek yang penting untuk membina hubungan teraupetik dan dapat mempengaruhi kualitas pelayanan keperawatan. Komunikasi terapeutik menjadi sangat penting karena dapat mempengaruhi tingkat kepuasan pasien terhadap pelayanan kesehatan yang diberikan. Komunikasi profesional bagi perawat yang direncakan dan dilakukan untuk membantu penyembuhan dan pemulihan pasien. ${ }^{3}$

Adanya keterampilan komunikasi terapeutik yang baik, perawat akan lebih mudah menjalin hubungan saling percaya dengan pasien, dan hal ini akan lebih efektif bagi perawat dalam memberikan kepuasan profesional dalam asuhan keperawatan dan setiap Rumah Sakit kepuasan pasien dipengaruhi oleh banyak faktor, salah satunya komunikasi teraupetik yang dilakukan oleh perawat. Komunikasi terapeutik yang baik akan memberikan kepuasan tersendiri oleh pasien, yang pada akhirnya akan mempengaruhi kepuasan pasien terhadap pelayanan yang diberikan di rumah Sakit. ${ }^{4}$

Kepuasan pasien adalah suatu tingkat perasaan pasien yang timbul sebagai akibat dari kinerja layanan kesehatan yang diperolehnya setelah pasien membandingkan dengan apa yang diharapkannya. Kepuasan akan tercapai apabila diperoleh hasil yang optimal bagi setiap klien dan keluarganya, ada perhatian terhadap keluhan, kondisi lingkungan fisik dan tanggap kepada atau memprioritaskan kebutuhan klien. ${ }^{5}$

Keberhasilan hubungan profesional terapeutik antara perawat dan klien sangat menentukan hasil tindakan yang di harapkan. Kepuasan pasien terdiri dari beberapa aspek, kinerja dan komunikasi merupakan aspek yang paling berkaitan erat dengan perawat karena memiliki intensitas interaksi dengan pasien paling tinggi dibandingkan petugas kesehatan lain di rumah sakit. Kedua aspek tersebut seharusnya menjadi fokus perhatian perawat ketika menolong pasien, kenyataan di lapangan menunjukkan bahwa banyak perawat yang belum menunjukkan sikap-sikap tersebut.

Perawat bukan hadir untuk melayani, namun terkesan menyelesaikan tugas pokok saja. Oleh karena itu, perawat perlu memiliki ketrampilan khusus untuk menambah nilai plus pada dirinya, salah satunya adalah dengan menguasai komunikasi terapeutik. ${ }^{6}$

Komunikasi terapeutik adalah pendekatan secara psikologis yang dilakukan atau dirancang untuk tujuan terapi. Fungsi komunikasi terapeutik adalah untuk mendorong dan mengajarkan kerja sama antara perawat dan pasien 
melalui hubungan perawat dan pasien. Hubungan saling memberi dan menerima antara perawat dan pasien dalam pelayanan keperawatan disebut sebagai komunikasi terapeutik perawat yang merupakan komunikasi profesional perawat. $^{7}$ Komunikasi dalam keperawatan disebut komunikasi terapeutik karena bertujuan untuk terapi. ${ }^{8}$

Komunikasi terapeutik diterapkan oleh perawat dalam berhubungan dengan pasien untuk meningkatkan rasa saling percaya, dan apabila tidak diterapkan akan menganggu hubungan terapeutik yang berdampak pada ketidakpuasan pasien. Pasien akan merasa puas ketika kinerja layanan kesehatan yang diperolehnya sama atau melebihi harapannya dan sebaliknya, ketidakpuasaan atau perasaan kecewa pasien akan muncul apabila kinerja layanan kesehatan yang diperolehnya itu tidak sesuai dengan harapannya. Komunikasi terapeutik ini sendiri memegang peranan penting dalam membantu pasien memecahkan masalah. ${ }^{9}$

Fitri Anggraini, (2013) dengan dalam penelitiannya menemukan adanya Hubungan Komunikasi Terapeutik Perawat Dalam Tindakan Keperawatan Dengan Kepuasan Klien Di Ruang Rawat Inap Rumah Sakit Umum Daerah Wates, Kulon Progo, Yogyakarta. ${ }^{1}$

Berdasarkan hal tersebut di atas maka perlu dilakukan penelitian tentang hubungan komunikasi terapeutik perawat terhadap kepuasan pasien rawat inap di Ruangan Interna Rumah Sakit Umum Daerah Poso.

\section{METODE}

Dalam peneltian ini mengunakan desain analitik korelasi dengan pendekatan cross sectional. ${ }^{11}$ Populasi dalam penelitian ini yaitu pasien rawat Inap di ruangan interna Rumah Sakit Umum Daerah (RSUD) Poso berjumlah 138 orang dengan jumlah sampel sebesar 49 responden. Penentuan sampel dengan menggunakan teknik purposive sampling dengan kriteria inklusi yaitu Pasien rawat inap di ruangan Interna RSUD Poso yang telah dirawat lebih dari 2 hari dan yang bersedia menjadi responden. Data diperoleh dengan menggunakan kuesioner yang teruji validitas dan realibilitasnya. Kuesioner berisi tentang komunikasi terapeutik dan kepuasan pasien terhadap pelayanan keperawatan yang dibagikan kepada responden. Komunikasi terapeutik dikategorikan baik dan kurang baik dengan menggunakan nilai median dimana kategori baik jika skor yang diberikan responden $\geq 62,5 \%$ Kurang baik $=$ jika $<$ $62,5 \%$. Data dianalisis dengan uji Statistik yaitu Chi-Square dengan menggunakan program SPSS.

\section{HASIL PENELITIAN}

Berdasarkan Tabel 1 menunjukkan bahwa karakteristik responden yang paling mendominasi penelitian ini adalah kategori umur 41-50 tahun (42,9\%). Berdasarkan jenis kelamin didominasi oleh perempuan yaitu sebanyak 26 responden dan yang lainnya adalah laki-laki sebanyak 23 responden.

Karakteristik pendidikan didominasi oleh responden berpendidikan SMA yaitu 23 responden, dan yang lainnya berpendidikan Perguruan Tinggi (15 responden, SMP (11 responden). Berdasarkan pekerjaan responden terbanyak adalah swasta yaitu sebanyak 18 responden, dan yang lainnya dengan pekerjaan sebagai petani/Irt sebanyak 16 responden serta jumlah terendah adalah PNS sebanyak 15 responden.

Tabel 5.2 menunjukkan bahwa komunikasi terapeutik perawat sebagian besar baik yaitu 31 responden $(63,3 \%)$, dan yang menunjukan komunikasi terapeutik perawat sebagian kecil kurang baik yaitu 18 responden (36,7\%). Tabel 5.3 menunjukkan bahwa 16 responden $(32,6 \%)$ menyatakan puas terhadap komunikasi terapeutik perawat. 


\section{HASIL PENELITIAN}

Tabel 1. Distribusi Karakteristik Responden di Ruang Interna RSUD Poso

\begin{tabular}{lcc}
\hline Karakteristik & Frekuensi & Persentase(\%) \\
\hline Umur & & 14,2 \\
$21-30$ tahun & 7 & 38,8 \\
$31-40$ tahun & 19 & 42,9 \\
$41-50$ tahun & 21 & 4,1 \\
$51-60$ tahun & 2 & 100 \\
Jumlah & 49 & \\
Jenis Kelamin & & 46,9 \\
Laki-laki & 23 & 53,1 \\
Perempuan & 26 & 100 \\
Jumlah & 49 & \\
Pendidikan & & 0 \\
SD & 0 & 22,4 \\
SMP & 11 & 46,9 \\
SMA & 23 & 30,7 \\
PT & 15 & 100 \\
Jumlah & 49 & \\
Pekerjaan & & 30,6 \\
PNS & 15 & 36,7 \\
SWASTA & 18 & 32,7 \\
TANI/IRT & 16 & 100 \\
Jumlah & 49 & \\
\end{tabular}

Tabel 2. Komunikasi Terapeutik Perawat di RSUD Poso

\begin{tabular}{ccc}
\hline $\begin{array}{l}\text { Komunikasi } \\
\text { Terapeutik }\end{array}$ & Frekuensi & $\begin{array}{c}\text { Persentase } \\
(\%)\end{array}$ \\
\hline Baik & 31 & 63,3 \\
Kurang & 18 & 36,7 \\
Jumlah & 49 & 100 \\
\hline
\end{tabular}

Tabel 3. Kepuasan Pasien di Ruang Interna RSUD Poso

\begin{tabular}{lll}
\hline Kepuasan Pasien & Frekuensi & $\begin{array}{c}\text { Persentase } \\
(\%)\end{array}$ \\
\hline Puas & 33 & 67,3 \\
Kurang Puas & 16 & 32,6 \\
Jumlah & 49 & 100 \\
\hline
\end{tabular}

Hubungan komunikasi terapeutik terhadap kepuasan pasien menunjukkan bahwa 31 responden yang mengatakan komunikasi terapeutik perawat baik, 26 responden $(83,9 \%)$ merasa puas dan 5 responden $(16,1 \%)$ merasa kurang puas terhadap pelayanan keperawatan. Terdapat 18 responden yang mengatakan komunikasi terapeutik perawat kurang baik, 8 responden $(44,4 \%)$ merasa puas dan 10 responden $(55,6 \%)$ merasa kurang puas terhadap pelayanan keperawatan (Tabel 4).

Berdasarkan hasil uji statistik dengan menggunakan Chi-Square menunjukkan adanya hubungan yang bermakna antara komunikasi terapeutik perawat dengan kepuasan pasien pada layanan kesehatan $(\mathrm{p}=0,01)$

Tabel 4. Hubungan Komunikasi Terapeutik Terhadap Kepuasan Pasien di Ruang Interna RSUD Poso

\begin{tabular}{llllllll} 
Komunikasi & \multicolumn{4}{c}{ Kepuasan } & Total & $\boldsymbol{\rho}$ \\
\cline { 2 - 6 } Terapeutik & Puas & \multicolumn{4}{c}{ Kurang Puas } & & \\
\hline & $\mathrm{n}$ & $\%$ & $\mathrm{n}$ & $\%$ & $\mathrm{n}$ & $\%$ & $\mathbf{0 , 0 1}$ \\
Baik & 26 & 83,9 & 5 & 16,1 & 31 & 100 & \\
Kurang baik & 8 & 44,4 & 10 & 55,6 & 18 & 100 & \\
Jumlah & 34 & 69,4 & 15 & 30,6 & 49 & 100 & \\
\hline
\end{tabular}


komunikasi terapeutik perawat dengan kepuasan pasien pada layanan kesehatan.

\section{PEMBAHASAN}

\section{Karakteristik Responden}

Berdasarkan hasil analisis ditinjau dari karakteristik umur sebagian besar berumur 41-50 tahun. Ada kecenderungan konsumen yang lebih tua lebih merasa puas dari konsumen yang berumur relatif lebih muda. Hal ini diasumsikan bahwa konsumen yang lebih tua telah berpengalaman, sehingga ia mampu menyesuaikan diri dengan kondisi pelayanan yang sebenarnya, sedangkan konsumen usia mudah biasanya mempunyai harapan yang ideal tentang pelayanan yang diberikan, sehingga apabila harapannya dengan realita pelayanan terdapat kesenjangan, atau ketidakseimbangan dapat meyebabkan mereka menjadi tidak puas. ${ }^{12}$

Ditinjau dari jenis kelamin sebagian besar responden pada penelitian ini lebih banyak wanita. Wahyu (2006) menyatakan bahwa jenis kelamin mempengaruhi persepsi dan harapan pasien untuk memenuhi kebutuhan termasuk pelayanan kesehatan. Wanita memiliki kecenderungan pekerjaan yang lebih berat dibanding laki-laki, sehingga lebih mudah terserang penyakit. ${ }^{13}$

Ditinjau dari pekerjaan responden sebagian besar adalah swasta dengan, pekerjaan juga erat kaitanya dengan kesehatan karena beban kerja berlebihan akan menimbulkan perasaan dikejar batas waktu penyesuaian tugas yang menyebabkan individu bekerja dengan kecepatan yang tinggi sehingga mudah merasa lelah, sehingga mengakibatkan gangguan kesehatan dan keletihan mengakibatkan banyak kekeliruan kerja karena daya konsentrasi menurun, banyak kecelakaan kerja, rasa tidak puas karena tugas tidak sempat dikerjakan. Ditinjau dari tingkat pendidikan sebagian besar yang berpendidikan SMA. Tingkat pendidikan seseorang akan cenderung membantunya untuk membentuk suatu pengetahuan sikap dan perilakunya terhadap sesuatu. Dengan pengetahuan yang baik seseorang dapat melakukan evaluasi berkaitan dengan kemampuan untuk melakukan justifikasi atau penilaian terhadap suatu materi atau objek yang ditentukan. Semakin tinggi tingkat pendidikan seseorang, maka daya untuk mengkritisi segala sesuatu akan meningkat. Sehingga seseorang dengan pendidikan yang lebih tinggi semestinya akan lebih kritis dalam menentukan apakah pelayanan yang telah diberikan dapat memberikan rasa puas atau tidak. ${ }^{14}$

\section{Komunikasi Terapeutik}

Dari penelitian didapatkan hasil bahwa sebagian besar komunikasi terapeutik perawat berada dalam kategori baik. Hal ini menunjukan bahwa komunikasi terapeutik memegang peranan penting memecahkan masalah yang dihadapi pada dasarnya komunikasi terapeutik merupakan komunikasi profesional yang mengarah pada tujuan yaitu penyembuhan pasien. ${ }^{15}$

\section{Kepuasan Pasien}

Berdasarkan tabel 3 menunjukkan bahwa sebagian besar responden yang menyatakan puas terhadap komunikasi terapeutik perawat. Ini berarti bahwa kepuasan pasien erat kaitanya dengan baik buruknya suatu pelayanan yang diterima oleh pasien, pengukuran kepuasan ini mutlak diperlukan melalui pengukuran tersebut dapat diketahui sejauh mana tingkat mutu pelayanan kesehatan yang diselenggarakan dapat memenuhi harapan pasien, kepuasan pasien merupakan salah satu tujuan dari peningkatan mutu pelayanan kesehatan. ${ }^{9}$

\section{Hubungan komunikasi terapeutik perawat dengan kepuasaan pasien rawat inap}

Berdasarkan hasil penelitian ini diperoleh sebagian besar responden menyatakan komunikasi terapeutik 
perawat dalam kategori baik dan merasa puas dengan pelayanan kesehatan yang diberikan. Namun ada juga pasien yang mersa kurang puas dengan pelayanan kesehatan yang diberikan. Hal ini menunjukkan komunikasi yang diberikan perawat dalam memberikan pelayanan keperawatan tentang informasi kesehatan tidak sesuai dengan harapan mereka dan perawat kurang memperhatikan tehniktehnik komunikasi terapeutik disisi lain rasio antara perawat dan pasien yang kurang memadai seperti diruang perawatan interna dimana ada tindakan/prosedur yang harus dilakukan oleh perawat sehingga terbatas waktu untuk berkomunikasi dengan pasien.

$\begin{array}{ccc}\text { Hasil } & \text { analisis } & \text { Chi-Square } \\ \text { menunjukkan } & \text { adanya } & \text { hubungan }\end{array}$
komunikasi terapeutik perawat dengan kepuasaan pasien rawat inap ruang Interna RSUD Poso ( $\mathrm{p}=0,01)$. Hasil penelitian ini sejalan dengan yang dikemukakan oleh Finley (2001) seperti dikutip dalam Wahyudi (2009) bahwa pasien baru akan merasa puas apabila kinerja layanan kesehatan yang diperolehnya sama atau melebihi harapannya dan sebaliknya, kurang puas atau perasaan kecewa pasien akan muncul apabila kinerja layanan kesehatan yang diperolehnya itu tidak sesuai dengan harapannya. ${ }^{16}$

Pada Penelitian yang juga dilakukan oleh Kusumo (2016) menemukan adanya pengaruh komunikasi terapeutik perawat terhadap kepuasan pasien di Poliklinik dan IGD RSUD kota Jogja. Dimana dalam penelitian ini pasien merasa puas dengan komunikasi terapeutik yang di lakukan perawat. ${ }^{17}$

Menurut Mapa (2009) kepuasan pasien terhadap komunikasi perawat merupakan tingkat perasaan seseorang pasien setelah membandingkan komunikasi perawat yang dirasakan dengan harapan yang diinginkan oleh pasien setelah menjalani rawat inap. ${ }^{17}$

Banyak faktor penyebab kurang puas pasien di rumah sakit, salah satunya adalah faktor komunikasi perawat. Kepuasan pasien sangat tergantung pada bagaimana faktor tersebut di atas dapat memenuhi harapan. Sebagai contoh; faktor komunikasi verbal dan non-verbal perawat dalam komunikasi terapeutik apabila dilaksanakan tidak sesuai dengan spirit dalam komunikasi tersebut maka yang dihasilkan adalah respon ketidakpuasan dari pasien. Kepuasan dapat dipengaruhi oleh karakteristik yang ada dalam diri pasien diantaranya yaitu: latar belakang sosial ekonomi, budaya, lingkungan fisik, pekerjaan, kepribadian, lingkungan hidup, dan diagnosis penyakit. ${ }^{14}$

Hasil ini sesuai dengan teori yang dikemukakan oleh Dwidiyanti (2008). Salah satu faktor yang mempengaruhi kepuasan pasien adalah memberikan pelayanan dengan komunikasi yang terapeutik. Perawat yang memiliki ketrampilan berkomunikasi secara terapeutik tidak saja akan menjalin hubungan rasa percaya pada pasien, mencegah terjadinya masalah legal, memberikan kepuasan profesional dalam pelayanan keperawatan dan meningkatkan citra profesi keperawatan serta citra rumah sakit. ${ }^{18}$

Aspek yang membuat pasien tidak puas adalah perawat kadangkala tidak memperkenalkan dirinya dan tidak menjelaskan dengan detail tentang fasilitas yang ada di rumah sakit dan kadangkala tidak memberikan informed consent ketika akan melakukan suatu tindakan pada pasien.

\section{KESIMPULAN}

Berdasarkan hasil penelitian ini maka disimpulkan sebagian besar komunikasi terapeutik perawat pada pasien rawat inap di ruangan interna RSUD Poso adalah baik. Sebagian besar pasien rawat inap di ruangan interna RSUD Poso merasa puas terhadap komunikasi terapeutik perawat di RSUD Poso. Ada hubungan antara komunikasi terapeutik perawat terhadap kepuasan pasien rawat inap diruangan interna RSUD Poso. 
UCAPAN TERIMA KASIH

Penulis Mengucapkan terima kepada semua pihak terutama STIKES Husada Mandiri Poso yang banyak berperan dalam pendanaan penelitian ini.

\section{DAFTAR PUSTAKA}

1. Departemen Kesehatan RI. (2009). Sistem Kesehatan Nasional. Jakarta : Depkes RI

2. Departemen Kesehatan RI. (2007). Keputusan Menteri Kesehatan Republik Indonesia Nomor 375/MENKES/SK/III/2007 tentang Standar Profesi Radiografer. Jakarta: Depkes RI.

3. Damayanti, Mukhripah. (2008). Komunikasi teraupetik dalam praktik keperawatan. PT Refika Aditama, Bandung.

4. Suryani. (2015). Komunikasi Terapeutik Teori \& Praktik, Ed 2, ECG, Jakarta.

5. Supranto, J. M. A. (2006). Pengukuran tingkat kepuasan pelanggan untuk meningkatkan pangsa pasar, Rineka Cipta, Jakarta

6. Simamora, R. (2013). Manajemen keperawatan, EGC, Jakarta.

7. Purwaningsih, W dan Karlina, I. (2012). Asuhan Keperawatan Jiwa. Yogyakarta : Nuha Medika.

8. Suryani. (2015). Komunikasi Terapeutik Teori \& Praktik, Ed 2, ECG, Jakarta.

9. Pohan, I, S. (2007). Jaminan mutu layanan kesehatan; dasar dasar pengertian penerapan, EGC, Jakarta.

10. Fitri Anggraini, (2013). Hubungan Komunikasi Terapeutik Perawat Dalam Tindakan Keperawatan Dengan Tingkat Kepuasan Klien di Ruang Rawat Inap Rumah Sakit Umum Daerah Wates Kulon ProgoYogyakarta.

ejournal.almaata.ac.id/index.php/JNKI /article/download/230/223.

11. Hidayat, (2007). Pengantar Konsep Dasar Keperawatan Edisi 2. Jakarta: Salemba Medika.
12. Anoraga, (2009). Psikologi Dalam Perusahaan. PT. RINEKA CIPTA:Jakarta.

13. Wahyu, E, (2006). Hubungan Pengetahuan Komunikasi Terapeutik Terhadap Kemampuan Komunikasi Perawat dalam melaksanakan Asuhan Keperawatan di Rumah Sakit Elisabeth Purwekerto. Jurnal Keperawatan Soedirman, Volume 1 Nomor 2 Nivember 2006.

14. Lestari, Sunarto, Kuntari. (2009) Analisa Faktor Penentu Tingkat Kepuasan Pasien di Rumah Sakit PKU Muhammadiyah Bantul, Jurnal Kedokteran dan Kesehatan Indonesia.Liliweri, A. 2007. Dasar dasar komunikasi kesehatan. Pustaka Pelajar: Yogyakarta

15. Liliweri, A. (2007). Dasar - dasar komunikasi kesehatan. Pustaka Pelajar: Yogyakarta

16. Kusumo, Mahendro Prasetyo. (2016). pengaruh komunikasi terapeutik perawat terhadap kepuasan pasien rawat jalan dan IGD di RSUD Kota Jogja. Jurnal Medicoeticolegal dan Manajemen RumahSakit. http://journal.umy.ac.id/index.php/mrs

17. Mapa, A.R. (2009) Hubungan Persepsi Pasien Tentang Komunikasi Perawat Dengan Kepuasan Pasien Terhadap Komunikasi di RSUP DR. Soeradji Tirtonegoro Klaten, Universitas Muhammadiyah Surakarta: Surakarta

18. Dwidiyanti, M. (2008). Keperawatan dasar: Konsep "caring”. Komunikasi, etik, dan spiritual dalam pelayanan kesehatan. Semarang: Hasani 